\title{
Effect of Adding L-Carnitine to Clomiphene Resistant PCOs Women on the Ovulation and the Pregnancy Rate Ahmed Taha Abd-Elfattah ${ }^{1 *}$, Mahmoud Abd-Ellatif Hashish², Fahd Abd El-aal Elomda ${ }^{1}$, Hossam Ibrahim Megahed ${ }^{1}$
}

Departments of ${ }^{1}$ Obstetrics \& Gynecology and ${ }^{2}$ Clinical Pathology, Faculty of Medicine, Al-Azhar University, Cairo, Egypt and Etay Elbaroud General Hospital, Ministry of Health *Correspondence author: Ahmed Taha Abd-Elfattah, Mobile: (+20) 01006257839, E-mail: dr.taha17@ yahoo.com

\begin{abstract}
Background: polycystic ovary (PCO) syndrome is an endocrionologic disorder that affecting about 6-10\% of women in their reproductive age. Conception rate with clomiphene citrate treated cycles is about $40 \%$ only and the number of ovulated oocyte decrease significantly with repeated cycles of ovulation.

Objective: evaluation of the effectiveness of usage of clomiphene citrate with L-carnitine (LC) in induction of ovulation in clomiphene citrate resistant patients. Patients and Methods: Randomized controlled study included a total number of 50 women with clomiphene-resistant PCOs. They were divided into 2 groups, group (A) where patients received 100 to $150 \mathrm{mg}$ clomiphene citrate from day three until day seven of the cycle and L-carnitine (LC) $3 \mathrm{~g}$ daily till positive pregnancy test and group (B) received 100 to $150 \mathrm{mg}$ clomiphene citrate with placebo.

Results: There was statistically significant difference (p-value $<0.05$ ) between both groups as regard infertility duration (months), ovulation rate, no. of chemical pregnancies and no. of clinical pregnancies. There was highly statistically significant difference ( $\mathrm{p}$-value $<0.001$ ) between both groups as regard days until HCG injection, endometrial thickness $(\mathrm{mm})$, no. of pre-ovulatory follicles $>17 \mathrm{~mm}$ and $\mathrm{E} 2$ on day of HCG injection.

Conclusion: Adding L-carnitine to clomiphene from the follicular phase and extending through the luteal phase in patients with clomiphene-resistant PCOS, at the given dose and duration, may be of beneficial to the quality of ovulation and the clinical pregnancy rate.
\end{abstract}

Keywords: L-carnitine, clomiphene-resistant, PCOs, pregnancy.

\section{INTRODUCTION}

Polycystic ovary syndrome (PCO) syndrome is one of the most common female endocrinological disorder, affecting about 6-10\% of women in their reproductive age. Mostly it presented with anovulation and hyperandrogenism together with hyperinsulinaemia and insulin resistance ${ }^{(\mathbf{1})}$.

Clomiphene citrate (CC) is considered the standard drug for ovulation induction ${ }^{(2)}$, Conception rate in clomiphene treated cycles is about $40 \%$ only, however the induced ovulation rates are between $80-85 \%$ (1).

It was found that Repeated ovulation induction decrease the quality of mitochondrial DNA and increase 8-hydroxydeoxy- guanosine in oocytes ${ }^{(3)}$.

The use of kinetic analysis has previously proved that the ovulated oocyte number decrease markedly with repeated cycles of ovulation. In addition, it was reported that a decrease in the gene expression of mitochondrial transcription factor $\mathrm{A}$ and a more incidence of oocyte with abnormally distributed mitochondria ${ }^{(4)}$.

It is common to start clomiphene citrate with 5omg then increase the dose up to $15 \mathrm{omg}$ and continuing the latter dose for three consecutive cycles. If no, ovulation occurred, this is called clomiphene citrate resistance ${ }^{(5)}$. There were many trials to improve the pregnancy rate in $\mathrm{CC}$ induction cycles through adjuvant treatment such as n-acetyl cysteine ${ }^{(6)}$.

Treatment of insulin resistance in women with PCO with an insulin sensitizer such as metformin dose increase pregnancy rate ${ }^{(7)}$.
Carnitine is a quaternary ammonium compound that can be synthesized from the two amino acids lysine and methionine ${ }^{(8)}$. In living cells, it helps in transport of fatty acids from cytoplasm into the mitochondria during the breakdown of lipids in the process of generating energy. It is present as nutritional supplement ${ }^{(8)}$.

There are two forms of stereoisomers of carnitine:

1- Carnitine which biologically active.

2- D-carnitine which biologically inactive ${ }^{(9)}$.

- Carnitene plays an essential role in energy production, oxidative stress and glucose metabolism ${ }^{(\mathbf{1 0})}$.

- Carnitine can stabilize organelle, and also protect the cell from apoptosis ${ }^{(11)}$.

Usage of carnitine in the treatment of insulin resistance has gained attention since the role of accumulation of acyl-coa derivatives in the development of insulin resistance was suggested. Furthermore, some recent studies point towards 1- carnitine insufficiency as a case of developing insulin resistance during stats of chronic metabolic stress, such as type2 D.M. and obesity that can be reversed by carnitine.

It was found that Women with PCO had lower level of serum 1- carnitine. The decrease was correlated to hyper androgenic and hyper-insulinaemia markers ${ }^{(\mathbf{1 2})}$.

\section{AIM OF THE WORK}

It is to evaluation of the effectiveness of usage of clomiphene citrate with L-carnitine in induction of ovulation in clomiphene citrate resistant patients. 


\section{PATIENTS AND METHODS}

Study setting:

This study has been carried out in the department of Obstetrics and Gynecology, Alhussain University hospital (outpatient infertility clinic) and Etay Elbaroud General hospital.

\section{Type of the study:}

Randomized controlled study was done to evaluate the effect of Adding L-Carnitine to clomiphene citrate resistant PCOs women on the quality of ovulation and the pregnancy rate.

\section{Ethical approval:}

The study was approved by the Ethics Board of Al-Azhar University and an informed written consent was taken from each participant in the study.

Fifty 50 Outpatient Infertility Clinic women were included in the study fulfilling the following inclusion and exclusion criteria:

\section{Inclusion criteria:}

1- PCO women.

2- Age $18-35$ years old.

3- Infertile women.

4- Clomiphene resistant received three cycles of induction with no ovulation.

\section{Exclusion criteria:}

1- Tubal factor infertility.

2- Male factor infertility.

3- No history of surgery or previous ovarian drilling before.

\section{They were divided into 2 groups:}

Group (A) (n=25): where patients received 1 oo to 150 mg clomiphene citrate from day three until day seven of the cycle plus L-carnitine (LC) 3g daily (till positive pregnancy test).

Group (B) $(\mathrm{n}=25)$ : received 100 to 15 o $\mathrm{mg}$ clomiphene citrate with placebo.

Patients included in this study were subjected to:

I- Written consent was obtained from the outpatient infertility clinic women that included in the study.

\section{II- Full History Taking Including:}

- Name, age, occupation and address.

- Obstetric history and $1^{\text {st }}$ day of last menstrual period (LMP).

- Medical or operative history.

- Any drug allergy or obstetric or operative complication.

III- Clinical Examination:

General examination:

- Vital signs: blood pressure, pulse, respiratory rate and temperature.
- Height (in $\mathrm{cm}$ ) and weight (in $\mathrm{kg}$ ) measurements while subjects were wearing the possible lightest clothing. and body mass index (BMI) was calculated at time of admission by using the Formula:

Weight in (kg)

\section{Height in (meters) ${ }^{2}$}

- Head and neck examination for jaundice, pallor, pigmentations, oedema, goiter, enlarged lymph nodes and congested neck veins.

- Limb examination for oedema, varicose veins, and deformities.

\section{Abdominal examination:}

- Inspection: to detect size of the abdomen, Striaegravidarum and pigmentations as lineanigra.

IV- Laboratory Investigations:

- $\mathrm{HB} \%$.

- RBS.

- Urine analysis.

- FSH.

- LH.

- PRoLACTIN.

- E2.

- TSH.

\section{V- Ultrasound:}

The criteria fulfilling sufficient specificity and sensitivity to define the PCO should have at least one of the following: either 12 or more follicles measuring 2-9 $\mathrm{mm}$ in diameter, or increased ovarian volume $(>10 \mathrm{~cm} 3)$. If there is a follicle $>10 \mathrm{~mm}$ in diameter, the scan should be repeated at a time of ovarian quiescence in order to calculate volume and area. The presence of a single PCO is sufficient to provide the diagnosis. The distribution of follicles and a description of the stroma are not required in the diagnosis. Increased stromal echogenicity and/or stromal volume are specific to PCO.

\section{RESULTS}

\section{Statistical analysis}

Data were analyzed using Statistical Program for S0cial Science (SPSS) versi0n 15.0. Quantitative data were expressed as mean \pm standard deviation (SD). Qualitative data were expressed as frequency and percentage.

The following tests were done:

Independent-samples t-test of significance was used when c0mparing between two means.

Chi-square test was used when c0mparing between n0nparametric data.

\section{Probability (P-value)}

- P-value $<0.05$ was considered significant.

- P-value $<0.001$ was considered as highly significant.

- P-value $>0.05$ was considered insignificant. 
Table (1): comparison between studied groups as regard age

\begin{tabular}{|c|c|c|c|c|}
\multicolumn{2}{|c|}{ Variables } & $\begin{array}{c}\text { Group A } \\
(\mathbf{N}=25)\end{array}$ & $\begin{array}{c}\text { Group B } \\
(\mathbf{N}=\mathbf{2 5})\end{array}$ & P-value \\
\hline $\begin{array}{c}\text { Age } \\
\text { (years) }\end{array}$ & Mean & 26.12 & 25.64 & 0.6 \\
\hline
\end{tabular}

Table (2): comparison between studied groups as regard BMI

\begin{tabular}{|c|l|c|c|c|}
\hline \multicolumn{2}{|c|}{ Variables } & $\begin{array}{c}\text { Group A } \\
(\mathbf{N}=\mathbf{2 5})\end{array}$ & $\begin{array}{c}\text { Group B } \\
(\mathbf{N}=\mathbf{2 5})\end{array}$ & $\begin{array}{c}\text { P- } \\
\text { value }\end{array}$ \\
\hline $\begin{array}{c}\text { BMI } \\
\left(\mathbf{k g} / \mathbf{m}^{2}\right)\end{array}$ & Mean & 31.22 & 31.79 & 0.5 \\
\hline
\end{tabular}

This table shows no statistical significant difference ( $p$-value $>0.05$ ) between studied groups as regard age.

Table (3): comparison between studied groups as regard No of pre-ovulatory follicles $>17 \mathrm{~mm}$

\begin{tabular}{|c|c|c|c|c|}
\hline \multicolumn{2}{|l|}{ Variables } & $\begin{array}{l}\text { Group A } \\
(\mathbf{N}=\mathbf{2 5})\end{array}$ & $\begin{array}{c}\text { Group B } \\
(\mathrm{N}=25)\end{array}$ & $\begin{array}{c}\text { P- } \\
\text { value }\end{array}$ \\
\hline \multirow{2}{*}{$\begin{array}{l}\text { Number of pre- } \\
\text { ovulatory follicles } \\
>17 \mathrm{~mm}\end{array}$} & & 2.68 & 1.20 & \multirow{2}{*}{$\begin{array}{l}<0.001 \\
* *\end{array}$} \\
\hline & & 0.95 & 0.41 & \\
\hline
\end{tabular}

**: $\mathrm{p}$-value $<0.001$ is considered highly significant.

In our study the number of pre-ovulatory follicles more than $17 \mathrm{~mm}$ was significantly ( $\mathrm{P}$ value $<0.001$ ) higher in group A $(2.68 \pm 0.95)$ and $(1.20 \pm 0.41)$ in group B.

Table (4): comparison between studied groups as regard ovulation rate

\begin{tabular}{|c|c|c|c|c|}
\hline \multicolumn{2}{|l|}{ 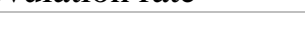 } & $\begin{array}{c}\text { Group A } \\
(\mathbf{N}=\mathbf{2 5})\end{array}$ & $\begin{array}{c}\text { Group B } \\
(\mathbf{N}=\mathbf{2 5})\end{array}$ & P-value \\
\hline Ovulation & Yes & $14(56 \%)$ & $4(16 \%)$ & 0.003* \\
\hline rate & No & $11(44 \%)$ & $21(84 \%)$ & \\
\hline
\end{tabular}

In our study in the ovulation rate there was significant difference between two groups as in group A ovulation occurred in 14 case (56\%) with 11 case did not ovulate (44\%) but in group B the ovulating case were 4 $(16 \%)$ only.

Table (5): comparison between studied groups as regard endometrial thickness $(\mathrm{mm})$

\begin{tabular}{|c|c|c|c|c|}
\hline \multicolumn{2}{|l|}{ Variables } & $\begin{array}{c}\text { Group A } \\
(\mathbf{N}=\mathbf{2 5})\end{array}$ & $\begin{array}{r}\text { Group B } \\
(\mathbf{N}=25)\end{array}$ & P-value \\
\hline \multirow{2}{*}{$\begin{array}{c}\text { Endo. } \\
\text { Thickness } \\
\text { (mm) }\end{array}$} & Mean & 11.49 & 5.88 & \multirow[t]{2}{*}{$<0.001 *$} \\
\hline & \pm SD & 1.78 & 1.25 & \\
\hline
\end{tabular}

*: p-value $<0.001$ is considered highly significant.
In our study endometrial thickness results shows highly statistical significant difference ( $p$-value $<0.001)$ between studied groups in $(\mathrm{mm})$ group A $(11.49 \pm 1.78)$ $\mathrm{mm}$ and group B $(5.88 \pm 1.25) \mathrm{mm}$.

Table (6): comparison between studied groups as regard days until HCG injection

\begin{tabular}{|c|c|c|c|c|}
\hline \multicolumn{2}{|c|}{ Variables } & $\begin{array}{c}\text { Group A } \\
(\mathbf{N}=\mathbf{2 5})\end{array}$ & $\begin{array}{r}\text { Group B } \\
(N=25)\end{array}$ & P-value \\
\hline Days until & Mean & 8.48 & 12.60 & $<0.001 *$ \\
\hline $\begin{array}{c}\text { HCG } \\
\text { injection }\end{array}$ & $\pm \mathrm{SD}$ & 2.35 & 1.87 & \\
\hline
\end{tabular}

Table (7): comparison between studied groups as regard E2 on day of HCG injection

\begin{tabular}{|c|c|c|c|c|}
\hline \multicolumn{2}{|l|}{ Variables } & $\begin{array}{c}\text { Group A } \\
(\mathbf{N}=\mathbf{2 5})\end{array}$ & $\begin{array}{r}\text { Group B } \\
(\mathbf{N}=25)\end{array}$ & P-value \\
\hline \multirow{2}{*}{$\begin{array}{l}\text { E2 on day of } \\
\text { HCG injection }\end{array}$} & Mean & 276.02 & 203.27 & \multirow[t]{2}{*}{$<0.001 *$} \\
\hline & & 18.12 & 13.43 & \\
\hline
\end{tabular}
significant.

$*$ : p-value $<0.001$ is considered highly

This table shows highly statistical significant difference (p-value $<\mathbf{0 . 0 5}$ ) between studied groups as regard E2 on day of HCG injection.

Table (8): comparison between studied groups as regard No of pregnancies

\begin{tabular}{|c|c|c|c|c|}
\hline \multicolumn{2}{|c|}{ Variables } & $\begin{array}{c}\text { Group A } \\
(\mathbf{N}=\mathbf{2 5})\end{array}$ & $\begin{array}{l}\text { Grou } \\
\text { p B } \\
(\mathbf{N}=\mathbf{2 5})\end{array}$ & $\begin{array}{l}\text { P- } \\
\text { value }\end{array}$ \\
\hline \multirow{2}{*}{$\begin{array}{l}\text { Number of } \\
\text { pregnancies }\end{array}$} & $\begin{array}{c}\text { Not } \\
\text { pregnant }\end{array}$ & $12(48 \%)$ & $\begin{array}{l}21 \\
(84 \%)\end{array}$ & \multirow[t]{2}{*}{$0.007 *$} \\
\hline & $\begin{array}{c}\text { Got } \\
\text { pregnant }\end{array}$ & $13(52 \%)$ & $\begin{array}{l}4 \\
(16 \%)\end{array}$ & \\
\hline
\end{tabular}

\section{DISCUSSION}

The problem of optimal follicular growth and good ovulation in CC-induced cycles presents a challenge to reproductive specialists ${ }^{(13)}$. There are many methods for management of clomiphene resistance in patients with PCOS including weigh reduction, insulin sensitizers such as metformin and the recently applied anti-oxidant effect of $\mathrm{N}$-acetyl cysteine. Some studies point towards L-carnitine insufficiency as a cause of emerging insulin resistance during states of chronic metabolic stress, such as Type II diabetes and obesity, which can be reversed by carnitine ${ }^{(\mathbf{1 4})}$.

L-carnitine is reported to have beneficial effect in the treatment of infertility ${ }^{(\mathbf{1 5}, \mathbf{1 6})}$; and as it is reported to be used as a potent antioxidant with little side effects and the researchers are now considering its implementation as a treatment for female infertility $(15,17$, 18). 
So, throughout the current study, we aimed to assess the effectiveness of L-carnitine on the occurrence of ovulation in PCO infertile women. Although there are a lot of clinical trials known in this regard, the results were varying.

In the current study, 5o outpatient clinic infertile women were included and divided into two group, first group consisted of 25 patients who received $150 \mathrm{mg}$ clomiphene citrate from day three until day seven of the cycle and L-carnitine (LC) $3 \mathrm{~g}$ daily tell positive pregnancy test and the second group consisted also of 25 patients who received placebo drug blindly.

In the present study in the ovulation rate there was significant difference between two groups as in group A ovulation occurred in 14 case $(56 \%)$ with 11 case did not ovulate (44\%) but in group B the ovulating occurred in $4(16 \%)$ only.

In study done by Ismail $\boldsymbol{e t}$ al. ${ }^{(17)}$ that was done in trial to evaluate the efficacy of LC on improving the ovulation and pregnancy rates as well as adverse metabolic indices in clomiphene-resistant PCOS women $17 \mathrm{o}$ clomiphene resistant PCOS women (aged less than 35 years) were randomly allocated into 2 groups: Group A $(\mathrm{n}=85)$ received $250 \mathrm{mg}$ clomiphene citrate plus Lc Group B $(\mathrm{n}=85)$ received $250 \mathrm{mg}$ clomiphene with placebo it was found that combination of LC and CC significantly improved both the ovulation and the pregnancy rates in clomiphene-resistant PCOS women ${ }^{(17)}$.

In the current study the number of pre-ovulatory follicles measuring more than $17 \mathrm{~mm}$ was significantly ( $\mathrm{P}$ value $<0.001)$ higher in group A $(2.68 \pm 0.95)$ and $(1.20 \pm 0.41)$ in group B.

Ismail et $\boldsymbol{a l} .{ }^{(17)}$ found in their trial to assess the efficacy of LC on improving the ovulation and pregnancy rates as well as adverse metabolic indices in clomiphene-resistant PCOS women 170 clomiphene resistant PCOS women (aged less than 35 years) were randomly allocated into 2 groups: Group A $(n=85)$ received $250 \mathrm{mg}$ clomiphene citrate plus Lc Group B (n $=85$ ) received $250 \mathrm{mg}$ clomiphene citrate with placebo regarding ovulatory follicle found that The number of stimulated follicles reaching $\geq 17 \mathrm{~mm}$ diameter was significantly higher in Group A as compared to Group $\mathrm{B}^{(17)}$.

In study done by Latifian et $_{\text {al. }}{ }^{(\mathbf{1 9 )})}$ that was done to examine the effect of adding LC to PCOS women who were resistant to clomiphene citrate and gonadotropin. 2 $\mathrm{g} \mathrm{LC}$ orally every $12 \mathrm{~h}$, given from the third day of treatment with clomiphene citrate and gonadotropin until the hCG injection. 5o PCOS patients (aged 2o-35 years) either received $\mathrm{LC}$ or did not receive $\mathrm{LC}$ found that women supplemented with LC-had increased left ovarian follicle size compared to those without LC, however right ovarian follicle size was not significantly different between both groups ${ }^{(19)}$.
The rationale of adding L-carnitine in the follicular phase is to revert the reactive oxygen species (ROS) and act as scavenger for the harmful oxidative stress substances accumulated by previous cycles of induction of ovulation. A trial performed by Kuscu and $\operatorname{Var}^{(20)}$ demonstrated up-regulated superoxide dismutase (SOD) activity in patients with PCOS compared to controls ${ }^{(20)}$. Fulghesu et al. $^{(\mathbf{( 2 1 )})}$ also evaluated the effect of N-acetyl- cysteine (NAC), known to replenish stores of the anti-oxidant glutathione, on insulin secretion and peripheral insulin resistance in subjects with PCOS. Their results revealed that oxidative stress associated with ovulation lies in the mechanism of ovarian aging. Furthermore, L-carnitine may have therapeutic effect in patients with infertility and high risk of aneuploidy, and may be able to suppress impaired zygote maturation usually observed in childbearing at an advanced age.

In the current study shows highly statistical significant difference ( $p$-value $<0.001)$ between studied groups in $(\mathrm{mm})$ group A $(11.49 \pm 1.78) \mathrm{mm}$ and group B $(5.88 \pm 1.25) \mathrm{mm}$ as regard endometrial thickness

In study done by Ismail $\boldsymbol{e t} \boldsymbol{a l} .{ }^{(17)}$ that was done to evaluate the effectiveness of LC on improving the ovulation rate and pregnancy rates as well as adverse metabolic indices in clomiphene-resistant PCOS women17o clomiphene resistant PCOS women (aged less than 35 years) were randomly allocated into 2 groups: Group A $(\mathrm{n}=85)$ received $250 \mathrm{mg}$ clomiphene citrate plus Lc Group B $(\mathrm{n}=85)$ received $250 \mathrm{mg}$ clomiphene citrate with placebo regarding endometrial thickness it was found that Endometrium at the time of hCG administration was significantly thicker in Group A.

Also in study done by Latifian et $_{\text {al }} .^{\left({ }^{(19)}\right.}$ that was done to examine the effect of adding LC to PCOS patients who were resistant to clomiphene citrate and gonadotropin. $2 \mathrm{~g} \mathrm{LC}$ orally every $12 \mathrm{~h}$, given from the third day of treatment with clomiphene citrate and gonadotropin until the day of hCG injection. 5o PCOS patients (aged 2o-35 years) either received LC or did not receive $L C$ it was showed that endometrial thickness was significantly thicker with LC.

In the current study the level of E2 on day of HCG injection shows higher values in group A $(276.06 \pm 18.12)$ and $(203.27 \pm 13.43)$ in group B

Ismail et al. ${ }^{(17)}$ found that Serum level of E2, on the day of hCG administration, was significantly higher in the LC group. in trial to assess the effectiveness of LC on improving the ovulation and pregnancy rates as well as adverse metabolic indices in clomiphene-resistant PCOS women 17o clomiphene resistant PCOS women (aged less than 35 years) were randomly allocated into 2 groups: Group A $(\mathrm{n}=85)$ received $250 \mathrm{mg}$ clomiphene citrate plus Lc Group B $(\mathrm{n}=85)$ received $25 \mathrm{omg}$ clomiphene citrate with placebo regarding serum E2. (17) 
In the current study the number of pregnancies was higher in group A 13 case (52\%) that became pregnant and 12 case ( $48 \%$ ) did not got pregnant but in group B there were 4 cases (16\%) got pregnant and 21 cases $(84 \%)$ did not got pregnant, that was significantly difference ( $\mathrm{P}$ value $<0.007$ ).

In study done by Ismail et $\boldsymbol{a l} .{ }^{(17)}$ that was done to evaluate the effectiveness of LC on improving the ovulation and pregnancy rates as well as adverse metabolic indices in clomiphene-resistant PCOS women17o clomiphene resistant PCOS women (aged less than 35 years) were randomly allocated into 2 groups:Group A $(\mathrm{n}=85)$ received $250 \mathrm{mg}$ clomiphene citrate plus Lc Group B $(\mathrm{n}=85)$ received 25omg clomiphene citrate plus placebo regarding pregnancy it was found that Pregnancy occurred in $42 / 85$ cycles in Group A (54.5\%) and 5/85 cycles in Group B (5.8\%) and this difference was significant statistically.

In study done by Latifian $\boldsymbol{e t}$ al. ${ }^{(\mathbf{1 9 )})}$ that was done to examine the effect of adding LC to PCOS patients who were resistant to clomiphene citrate and gonadotropin. 2 g LC orally every $12 \mathrm{~h}$, given from the third day of treatment with clomiphene citrate and gonadotropin until the day od hCG injection. 50 PCOS patients (aged 2o35 years) either received LC or did not receive LC it was found that LC- treated women showed the growth of dominant follicles $(64 \%, 32 / 50$ therapeutic cycles) and displayed a positive pregnancy test $(20 \%, 10 / 50$ therapeutic cycles.

Basal serum FSH, LH, and free testosterone level were the same in both groups on the day of hCG administration during the cycles in which clomiphene plus L-carnitine or clomiphene plus placebo were given. A previous study performed by Ismail et al. ${ }^{\left({ }^{(17)}\right.}$ in Assiut University, Egypt that was done to assess the rate of fertility in women with PCOs after addition of Lcarnitine showed same demography. They performed randomized trial in which patients received $250 \mathrm{mg}$ clomiphene citrate from day three until day seven of the cycle plus L-carnitine (LC) $3 \mathrm{~g}$ daily in group A (LC group) and the other group $\mathrm{B}$ received $25 \mathrm{o} \mathrm{mg}$ clomiphene citrate plus placebo and their demographic data showed also that there was no evidence of statistically significant differences as regard age, infertility type, infertility duration, and body mass index, Basal serum FSH and LH between the two groups.

In the present study the Age and BMI were not statistically significant between the two groups.

\section{CONCLUSION}

Addition L-carnitine to clomiphene citrate in the follicular phase and extending through the luteal phase in patients with clomiphene-resistant PCOS, at the given dose and duration, may have significant role in improving the quality of ovulation and the clinical pregnancy rate.

\section{ACKNOWLEDGMENT}

Sincere appreciation and gratitude to Dr. Fahd Abd El-aal Elomda, Professor of Obstetrics and Gynecology, Faculty of Medicine, Al-Azhar University for his support all through the whole work and for valuable guidance, and follow up of the progress of this work. I owe him more than I can express. I have been greatly honored by his supervision. Profound and ultimate gratitude is expressed to Dr. Ahmed Taha AbdElfatah, Ass. Professor of Obstetrics and Gynecology, Faculty of Medicine, Al-Azhar University. His continuous help in following up the progress of the work, encouragement and support were certainly the most helpful steps in accomplishing this work. Finally deepest thanks and great appreciation for all my colleagues who helped me in the production of this work, and Dr. Mahmoud hashesh Ass. Professor of clinical pathology Alazhar university cairo, Sincere appreciation and gratitude to Dr. Abd-Elhalim Mohamed, Lecturer of Gynecology and Obstetrics, Al-Azhar University, Assiut, Egypt for his support all over the work.

\section{REFERENCES}

1. Knochenhauer ES, Key TJ, Kahsar-Miller M, Waggoner W, Boots LR, Azziz R (1998): Prevalence of the Polycystic Ovary Syndrome in Unselected Black and White Women of the Southeastern United States: A Prospective Study. J Clin Endocrinol Metab., 83(9):3078-82.

2. Trivax B, Azziz R (2007): Diagnosis of Polycystic Ovary Syndrome. Clin Obstet Gynecol., 50(1):168-77.

3. Miyamoto K, Sato EF, Kasahara E, Jikumaru M, Hiramoto K, Tabata $H$ (2010): Effect of oxidative stress during repeated ovulation on the structure and functions of the ovary, oocytes, and their mitochondria. Free Radic Biol Med., 49(4):674-81.

4. Ringseis R, Keller J, Eder K (2012): Role of carnitine in the regulation of glucose homeostasis and insulin sensitivity: evidence from in vivo and in vitro studies with carnitine supplementation and carnitine deficiency. Eur J Nutr., 51(1):1-18.

5. Rizk AY, Bedaiwy MA, Al-Inany HG (2005): N-acetylcysteine is a novel adjuvant to clomiphene citrate in clomiphene citrate-resistant patients with polycystic ovary syndrome. Fertil Steril., 83(2):367-70.

6. Badawy A, Baker EI Nashar A, El Totongy M (2006): Clomiphene citrate plus $\mathrm{N}$-acetyl cysteine versus clomiphene citrate for augmenting ovulation in the management of unexplained infertility: a randomized double-blind controlled trial. Fertil Steril., 86(3):647-50.

7. Balen AH, Dresner M, Scott EM, Drife JO (2006): Should obese women with polycystic ovary syndrome receive treatment for infertility? BMJ., 332(7539):4345.

8. STEIBER A, Kerner J, Hoppel CL (2004): Carnitine: a nutritional, biosynthetic, and functional perspective. Mol Aspects Med., 25(5-6):455-73.

9. Krysiak R, Okopień B, Gdula-Dymek A, Herman ZS (2019): Update on the management of polycystic ovary syndrome. Pharmacol Rep., 58(5):614-25. 
10. Vanella A, Russo A, Acquaviva R, Campisi A, Di Giacomo C, Sorrenti V (2000): L -propionyl-carnitine as superoxide scavenger, antioxidant, and DNA cleavage protector. Cell Biol Toxicol., 16(2):99-104.

11. Pillich RT, Scarsella G, Risuleo G(2005): Reduction of apoptosis through the mitochondrial pathway by the administration of acetyl-1-carnitine to mouse fibroblasts in culture. Exp Cell Res., 306(1):1-8.

12. Fenkci SM, Fenkci V, Oztekin O, Rota S, Karagenc $\mathbf{N}(\mathbf{2 0 0 8})$ : Serum total L-carnitine levels in non-obese women with polycystic ovary syndrome. Hum Reprod., d 23(7):1602-6.

13. Fujii S, Fukui A, Fukushi Y, Kagiya A, Sato S, Saito Y (1997): The effects of clomiphene citrate on normally ovulatory women. FertilSteril., 68:997-9.

14. Ringseis R, Eder K, Keller J(2012): Role of carnitine in the regulation of glucose homeostasis and insulin sensitivity: evidence from in vivo and in vitro studies with carnitine supplementation and carnitine deficiency. Eur J Nutr., (1):1-18., 51.

15. Dunning KR, Robker RL(2012): Promoting lipid utilization with 1-carnitine to improve oocyte quality. AnimReprod Sci., 134:69-75.

16. Abdelrazik H, Agarwal A (2009): L-carnitine and assisted reproduction. Arch Med Sci., 1:43-7.
17. Ismail AM, Hamed AH, Saso S, Thabet HH(2014): Adding L-carnitine to clomiphene resistant PCOS women improves the quality of ovulation and the pregnancy rate. A randomized clinical trial.Eur $\mathrm{J}$ ObstetGynecolReprod Biol., 180:148-52.

18. Samimi M, Jamilian M, Ebrahimi FA, Rahimi M(2016): Oral carnitine supplementation reduces body weight and insulin resistance in women with polycystic ovary syndrome: a randomized, double-blind, placebocontrolled trial. ClinEndocrinol., 84:851-7.

19. Latifian S, Hamdi K, Totakneh R(2015): Effect of addition of 1-carnitine in polycystic ovary syndrome (PCOS) patients with clomiphene citrate and gonadotropin resistant. Int J Curr Res Acad Rev., 3:46976.

20. Kuscu NK, Var A(2009): Oxidative stress but not endothelial dysfunction exists in non-obese, young group of patients with polycystic ovary syndrome. ActaObstetGynecol Scand., 88:612-7.

21. Fulghesu AM, Ciampelli M, Muzj G et al.(2002): Nacetyl cysteine treatment improves insulin sensitivity in women with polycystic ovary syndrome. FertilSteril., 77(6):1128-35. 